\title{
Belgeo
}

Revue belge de géographie

3-4 | 2008

Formatting Europe - Mapping a Continent

\section{Editorial: Formatting Europe -Mapping a Continent}

\section{Wulf Bodenstein}

\section{(2) OpenEdition}

\section{Journals}

\section{Electronic version}

URL: http://journals.openedition.org/belgeo/7653

DOI: 10.4000/belgeo.7653

ISSN: 2294-9135

\section{Publisher:}

National Committee of Geography of Belgium, Société Royale Belge de Géographie

\section{Printed version}

Date of publication: 31 December 2008

Number of pages: 241-244

ISSN: 1377-2368

\section{Electronic reference}

Wulf Bodenstein, "Editorial: Formatting Europe -Mapping a Continent", Belgeo [Online], 3-4 | 2008

Online since 22 May 2013, connection on 05 February 2021. URL: http://journals.openedition.org/ belgeo/7653 ; DOI: https://doi.org/10.4000/belgeo.7653

This text was automatically generated on 5 February 2021.

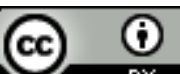

Belgeo est mis à disposition selon les termes de la licence Creative Commons Attribution 4.0 International. 


\title{
Editorial: Formatting Europe - Mapping a Continent
}

\author{
Wulf Bodenstein
}

The BIMCC gratefully acknowledges the support received from its usual Sponsors and Benefactors (see www.bimcc.org) and, in particular, the special effort made by:

Antiquariaat Plantijn, Chaam (NL), www.plantijnmaps.com

Antiquariaat Sanderus, Gent (B), www.sanderusmaps.com

Dieter Bohrmann, Hasselt (B)

Henri Godts, Brussels (B), www.godts.com

Puilaetco Dewaay Private Bankers, Brussels (B), www.puilaetcodewaay.be

The Romantic Agony Book Auctions, Brussels (B), www.romaticagony.com

Paulus Swaen Internet Auctions, Paris (F), www.swaen.com

The organization of the conference benefited from a financial aid by the Belgian science policy (F7835/0700066/058)

Europalia, the largest cultural festival in Europe, is staged every two years in Brussels and in Belgium to celebrate the cultural heritage of one invited country. Between 1969 and 2005 twenty festivals have been organized, attracting fifteen million visitors. In 2007 , the theme for the $21^{\text {st }}$ edition of Europalia was europalia.europa, devoted to all 27 member states of the European Union, to commemorate the signing of the Treaty of Rome fifty years ago, the beginning of one of the most audacious and visionary European endeavours of our lifetime.

A first contact with the Europalia Team in June of 2006 opened the possibility of integrating into this vast programme a cartographic component with two facets: the Brussels International Map Collectors' Circle (BIMCC) would organize an international conference on the history of the mapping of Europe, and the Royal Library of Belgium (KBR) would mount an exhibition of ancient maps of the continent. The ensuing most fruitful tri-partite cooperation resulted in the creation of the common project that became known under the heading of Formatting Europe - Mapping a Continent. The conference took place on $16^{\text {th }}$ November 2007 , and the exhibition ran from $17^{\text {th }}$ November 2007 to $8^{\text {th }}$ February 2008. 
For an event of this importance it was considered essential to publish the proceedings of the conference, and the BIMCC was most fortunate in obtaining the support of the Royal Geographical Society of Belgium to produce these, together with a number of supporting articles, in a special issue of the Journal Belgeo.

The essays published here stem from six of the eight lectures given at this conference ${ }^{1}$, to which have been added six chapters by invited map historians who, together, represent seven European countries. Their texts are presented in English, French and Dutch. Arranged in chronological order of subject, the topics range from medieval Arab cartography to maps with a political tint of the mid- $20^{\text {th }}$ century.

In his introduction to these proceedings, Wouter Bracke, Head of the KBR's Map Department, sets the scene by giving a broad overview of L'Europe dans la cartographie occidentale.

The first contribution, by Jean-Charles Ducène (Université Libre de Bruxelles), discusses L'Europe dans la cartographie arabe médiévale, describing the evolution of the Arab vision of Europe from Ptolemy's heritage to al-Idrîsî in the $12^{\text {th }}$ century.

H.A.M. van der Heijden (Steensel, The Netherlands) has honoured us with what he terms his last publication. He has published widely on Dutch cartography, and in his chapter on Gedrukte kaarten van Europa voór Ortelius. Een toevoegsel reviews the maps of Europe produced before Ortelius published his Theatrum Orbis Terrarum in 1570. Former curator of maps at the Bibliothèque nationale de France in Paris, Monique Pelletier analyzes Renaissance geographers' perception of Europe. Her article L'Europe vue par les géographes de la Renaissance expands on the preceding chapter and places the representation of Europe in a wider, global context of the depiction of the world. Introducing the earliest Swedish cartographer, conference Speaker Leena Miekkavaara (map curator, National Library of Finland), then opens up Scandinavia with The Mapping of the Northern Countries by Olaus Magnus in 1539. In her talk she described one of the largest maps of its time, the Carta marina by Olaus Magnus which became a model for the representation of Nordic lands for almost a century and has fascinated map historians to this day.

The conference's next presentation was by Krystyna Szykula (Head of the Wroclaw University Cartographic Department (retired)) who talked about Anthony Jenkinson's unique wall map of Russia (1562) and its influence on European cartography, an extraordinary map she had discovered herself in 1987 under astonishing circumstances.

Widening the scope beyond purely cartographical issues, Rodney Shirley (Buckingham, UK), probably best known for his cartobibliography The Mapping of the World, in the following chapter introduces us to Allegorical images in some atlas titlepages,

frontispieces and map cartouches. The discussion of these intriguing images and symbols focuses on the representation of Europe personified.

The contribution by well-known map historian Peter Meurer (Heinsberg, Germany) continues in a similar vein: Europa Regina $-16^{\text {th }}$ century maps of Europe in the form of a Queen addresses anthropomorphic maps showing Europe with the outlines of a female figure and the origins of this symbolism in contemporary politics.

Town views and plans introduced by Speaker Peter van der Krogt (Utrecht University) follow under the heading Mapping the Towns of Europe: The European towns in Braun \& Hogenberg's own Atlas, 1572-1617. Produced contemporarily with Ortelius's Theatrum this atlas achieved similar fame and is a most valued collectors' item. 
Moving to the $19^{\text {th }}$ century, Bernard Jouret, former Director of the Belgian Institut géographique national, gave his talk on The space perception of the relief of Europe by contour lines : the remarkable work of J.-C. Houzeau, edited in 1857. The resulting hypsometric map represents a mile stone in the scientific cartography of Europe in that time. A hand-coloured copy, published by Vandermaelen's Etablissement géographique, was on display in the Exhibition.

Speaker Gilles Palsky (Université de Paris 1) with his presentation on Connections and exchanges in European thematic cartography. The case of the $19^{\text {th }}$ century choropleth maps, introduced us to the work of Charles Dupin who is credited with having devised the first shaded map. Its origin and later impact on thematic mapping in the first half of the $19^{\text {th }}$ century is discussed, as is the role these maps played in what is now called 'social sciences'.

With the last two chapters we cast some light again on subjects not often addressed in the specialized cartographic literature. Adrian Seville (Chislehurst, UK) contributes a paper on The Geographical Jeux de l'Oie of Europe, tracing the story of the application of this game to the teaching of geography from Pierre Duval (1662) to $20^{\text {th }}$ century tourist promotion.

Political cartoon maps of Europe are another fascinating aspect as a side issue to classical cartographic discipline. Roderick Barron (Sevenoaks, UK) familiarizes us with this topic by Bringing the map to life: European satirical maps 1845 - 1945. One hundred years of Europe caricaturized are here displayed and analyzed and most eloquently demonstrate the immanent national animosities before Europe could finally begin to live without these.

The BIMCC acknowledges with gratitude the support obtained from Europalia International under the distinguished leadership of General Director Kristine De Mulder, and her assistants, in particular Dirk Vermaelen and Bloeme van Roemburg. The patronage of Patrick Lefèvre, Director General of the Royal Library, who hosted our conference and the reception, aided by a most competent group of collaborators, was highly appreciated, as was the excellent cooperation with the Head of the KBR's Map Department, Wouter Bracke, who efficiently integrated two BIMCC specialists, Lisette Danckaert and Caroline Decandt, into his team preparing the exhibition and catalogue. I am sincerely grateful to Günter Schilder (Utrecht University), one of the most profiled European map historians, for having accepted to be the conference chairman. My personal thanks go to the speakers and other authors, all of whom most amiably responded to my request to participate in this sequence of memorable lectures and scholarly contributions. The BIMCC is also much indebted to the Sponsors (see page 244) whose generous support on this special occasion was instrumental in enabling our Circle to serenely face the enormous challenges that were before us. Without undue exaggeration it may be said that the exemplary help and encouragement we obtained from all external associates as well as from our own untiring members resulted in making this the most successful event in the ten years of existence of the BIMCC. JeanLouis Renteux, Editor of the BIMCC Newsletter, here deserves a special mention of our gratefulness for his dedicated and unfailing performance in the editorial work around the conference and this publication.

Finally, our sincere thanks are due to the President of the Royal Geographical Society of Belgium, Christian Vandermotten, and to Benjamin Wayens, its Secretary, for having facilitated the publication of this special issue of Belgeo. Catherine Patris is to be thanked for coordinating the important tasks of the editorial team. 
May this exceptional publication contribute to achieving at least two things: give welldeserved credit to the individual authors, and in doing so, pay tribute to the European dimension manifest in both the thematic diversity and rational coherence of these contributions to the History of Cartography.

\section{NOTES}

1. The presentations by Angelo Cattaneo, Europe on late Medieval and early Renaissance world maps: provincializing Europe, and by Markus Heinz, Europe as seen by the Homann publishing firm in Nürnberg in the $18^{\text {th }}$ century, are available in the form of abstracts only, in the conference handout.

\section{AUTHOR}

\section{WULF BODENSTEIN}

BIMCC President 1998-2008 